\title{
PRECYZJA I NIEDOOKREŚLONOŚĆ WYRAŻEŃ W PRZEPISACH PRAWNYCH NA PRZYKLADZIE JEZZYKA POLSKIEGO I WĘGIERSKIEGO
}

\author{
Karolina KACZMAREK, dr \\ Instytut Językoznawstwa, Uniwersytet im. Adama Mickiewicza w Poznaniu \\ al. Niepodległości 4, 61-874 Poznań \\ e-mail: karkacz@amu.edu.pl
}

\begin{abstract}
Abstrakt: Tematem artykułu jest problematyka zwiąana $\mathrm{z}$ dwoma nurtami w filozofii prawa, według których prawo z jednej strony powinno być formułowane w sposób ogólny, by zawrzeć rozwiązanie dla wielu przypadków w różnych okolicznościach, a $\mathrm{z}$ drugiej strony powinno być dokładnie sprecyzowane tak, by obywatel wiedział z pewnościa, co może, a czego nie może czynić. W artykule wskazane sa narzędzia prawne i językowe, które w taki sposób wpływają na formułowanie i odczytywanie przepisów, by zostały spełnione oba te kryteria. W pierwszej części artykułu wymienione zostają niektóre rodzaje wykładni prawa, które są szczególnie ściśle powiązane z językiem jako narzędziem pozwalającym formułować przepisy oraz niektóre zasady interpretacji tekstu prawnego. W drugiej części omówione są cechy języka istotne dla interpretacji tekstów prawnych, przede wszystkim w odniesieniu do zakresów znaczeniowych wyrazów, w tym wyrażeń niedookreślonych i nieostrych. W części trzeciej autorka wskazuje na narzędzia językowe, które pozwalają zwiększyć precyzję tekstowa, takie jak definicje, wykorzystanie kontekstu, określanie granic nieostrości, wprowadzanie zdań warunkowych itd. Ostatnia część poświęcona jest wyrazom niedookreślonym, grupowanym według kategorii gramatycznych. Za materiał do badań empirycznych posłużyło przede wszystkim prawo polskie i węgierskie.
\end{abstract}

\section{PRECISION AND VAGUENESS IN THE LANGUAGE OF THE LAW IN HUNGARIAN AND POLISH LEGAL TEXTS}

\begin{abstract}
The article discusses two issues connected with the philosophy of law. On the one hand, the law should be formulated in a general way, because it must be applicable in many relevant situations. On the other, it should be precise, because people should be aware exactly of what they can do and what is forbidden to them. In the article the author points out such features of law and language which influence a text to help formulate and interpret it in a particular way that meets both criteria: to be vague and yet enough precise. In the first part, the article points out some kinds of interpretation in law which are especially closely connected with language level. In the second part, the author discusses such features of language which are important when we interpret those texts which are legal, especially the semantic meaning of some vague expressions. In the third part the author points out such language features which may help to make a text more precise, such as definitions, context and other ways of making terms more precise. In the last section the author points out some vague expression grouped grammatically. As the base of her empirical research the author has used Polish and Hungarian legal texts.
\end{abstract}

Słowa kluczowe: przepis prawny, akt normatywny, język prawny, precyzja w języku prawnym, niedookreśloność w języku prawnym 


\title{
A SZAKSZAVAK PONTOSSÁGA ÉS ÁLTALÁNOSSÁGA LENGYEL ÉS MAGYAR JOGI SZAKSZÖVEGBEN
}

\begin{abstract}
Absztrakt: A cikk témája két jog filozófiával kapcsolatos problémáról szól. Az egyik irányzat szerint a jogot minél általánosabban kell megfogalmazni, hogy minél több esetben, és minél tágabb körülmények között alkalmazható legyen. A másik irányzat írány szerint a jogot nagyon szabatosan, nagy pontossággal kell megfogalmazni, azért, hogy az ember könnyen átláthassa mit szabad, és mit nem szabad csinálnia. A cikkben olyan lengyel és magyar nyelvi eszközöket tárgyalunk, amelyek mind a két kritérium alkalmazását segítik.
\end{abstract}

\section{Wprowadzenie}

W opinii wielu badaczy prawa, legislatorów i prawników wskazane jest, aby prawo spełniało równocześnie dwa warunki: powinno być formułowane w sposób generalny, ale równocześnie być precyzyjne. Wynika to z faktu, iż z jednej strony istnieje potrzeba ścisłego określania obowiązków obywateli, zakazów i nakazów, z drugiej strony trzeba uwzględnić wielość przypadków, jakie powinny być rozpatrywane w odniesieniu do danego przepisu prawnego. Zasada generalności w prawie powoduje, że w momencie stosowania prawa osoby je interpretujące napotykają wyrażenia nie do końca zdefiniowane i w związku $\mathrm{z}$ tym zmuszone są do dokonywania wyborów na wielu poziomach, między innymi na poziomie leksykalnym, syntaktycznym czy tekstowym. Konieczność dokonywania wyborów wynikających z nieprecyzyjności tekstu dotyczy także tłumaczy aktów prawnych. $Z$ tego względu zagadnieniem precyzyjności języka prawa zajmują się nie tylko prawnicy, ale również lingwiści i tłumacze (por. Grzybek 2009, 207-215, Matulewska 2007, 121-122).

Zazwyczaj legislatorzy starają się ustalić pewne minimalne reguły pisania tekstów prawnych. W polskim prawodawstwie zasady takie sformułowane sa na przykład w Rozporzqdzeniu Prezesa Rady Ministrów z dnia 2 czerwca 2002 roku w sprawie Zasad techniki prawodawczej (Dz. U. z 2002 r. Nr 100 poz. 908). Jednakże, ze względu na kompleksowość problematyki, wydaje się, że nie jest możliwe sformułowanie tego typu wskazówek w sposób wyczerpujący tak, by tekst prawny był całkowicie jednoznaczny.

\section{Wykładnia prawa}

Zjawiskiem nieprecyzyjności języka prawa tradycyjnie zajmowała się filozofia prawa. W celu ustalenia znaczeń wprowadzono pojęcie wykładni, czyli inaczej interpretacji prawa, wyznaczając dla niej określone zasady. W myśl definicji polskich teoretyków prawa (Stawecki i Winczorek 2002, 151).

\footnotetext{
„Wykładnia prawa jest to proces ustalania właściwego znaczenia przepisów prawnych, odkodowanie zawartych w nich norm postępowania, udzielenie odpowiedzi na pytanie: kto, co i w jakich okolicznościach powinien czynić”.
} 


\subsection{Rodzaje wykładni}

Polskie zasady interpretacji wskazują na wiele rodzajów wykładni, istnieje na przykład wykładnia:

(i) systemowa - polega na ustalaniu rzeczywistego znaczenia przepisów ze względu na ich usytuowanie w ramach systematyki prawa,

(ii) funkcjonalna - polega na ustaleniu znaczenia przepisu zgodnie $\mathrm{z}$ domniemanym celem ustawodawcy,

(iii) porównawcza - polega na ustaleniu znaczenia przepisów przez porównanie ich z innymi, podobnymi przepisami o ustalonym już znaczeniu (por. Stawecki i Winczorek 2002, 162-163, Kaczmarek 2011, 45).

\subsection{Interpretacja tekstowa}

Przechodząc do lingwistycznej interpretacji tekstu, można zauważyć, że wśród teoretyków prawa na całym świecie zarysowują się dwie wyraźne tendencje co do sposobu interpretacji tekstów: wykładnia literalna i dyskursywna.

\subsubsection{Zasada interpretacji literalnej}

W myśl zasady wykładni literalnej, słowa tekstu należy rozumieć możliwie dosłownie. Jednakże, ponieważ tekst nigdy nie będzie całkowicie precyzyjny, najczęściej zachodzi konieczność jakiejś jego interpretacji, a osoby podejmujące decyzję co do określenia znaczenia tekstu prawnego w konkretnej sytuacji zmuszone będą do przełamywania nieprecyzyjności, kierując się zasadą rozsądku. Na gruncie polskim podejście takie będzie zbieżne z tzw. wykładnią językowo-logiczna. Polega ona na dokonywaniu interpretacji przepisów prawnych przy wykorzystaniu reguł znaczeniowych (semantycznych) i konstrukcyjnych (syntaktycznych, stylistycznych) języka prawnego i naturalnego, a także na zastosowaniu reguł poprawnego myślenia (logiki formalnej) i specyficznych reguł logiki prawniczej (quasi-logicznych) (Stawecki i Winczorek 2002, 162-163). Ostatni termin dotyczy stosowania w wykładni tzw. reguł interferencyjnych oznaczających, że jeżeli coś jest nieustalone, to stosuje się to $\mathrm{w}$ drodze analogii $\mathrm{z}$ innym przepisem, dotyczącym kwestii podobnych (por. Kaczmarek 2011, 45).

\subsubsection{Zasada interpretacji dyskursywnej}

W przypadku sformułowań ogólnych istnieje z jednej strony zagrożenie, że prawo przestanie być wartością obiektywną i zbyt wiele zależeć będzie od subiektywnej oceny wybranych osób, na przykład sędziów. Z drugiej strony, ponieważ dana zasada prawna będzie stosowana za każdym razem w nieco odmiennej sytuacji, całkowite jej sprecyzowanie nie jest możliwe. Kodeksy cywilne niektórych krajów europejskich zakładaja, że rozstrzygające $\mathrm{w}$ umowie są rzeczywiste intencje stron, a nie zapis słowny. Na przykład w kodeksie hiszpańskim, w art. 1281 stwierdza się, że jeżeli wyrażenia umowy są jasne i nie pozostawiają watpliwości co do intencji umawiających się stron, 
klauzule należy odczytywać literalnie. Jeżeli natomiast pojawią się wątpliwości co do intencji stron, sens klauzul należy odczytywać według ich sensu, a nie literalnego zapisu. Z kolei w Stanach Zjednoczonych spotyka się odmienne sposoby interpretacji, w zależności od zwyczaju panującego w danym stanie (por. Solan 2005, 78).

W historii myśli prawnej wielokrotnie zasady interpretacji starano się formułować w taki sposób, by były one sprawiedliwe, a nie żeby odzwierciedlały literę prawa. Jednym $\mathrm{z}$ przykładów tego typu metody może być the canon of contra proferentem. W myśl tej zasady $\mathrm{w}$ cywilnych dokumentach prawnych, takich jak na przykład umowy, wattpliwości powinny być rozstrzygane przede wszystkim na korzyść strony, która nie była autorem dokumentu. Wymiar sprawiedliwości stał na stanowisku, że strona formułująca tekst ma od początku większą możliwość uniknięcia niejasności $\mathrm{i}$ to ona powinna ponosić wszelkie konsekwencje, jakie wynikaja z niedbałego zapisu. Autorzy tejże formuły zauważyli również, że strona formułująca dokument często bywa silniejsza ekonomicznie od drugiej strony, co daje jej od początku pewną przewagę (por. Tiersma 2005, 120).

Wymienione wyżej nurty wydają się być sprzeczne ze sobą, dlatego stanowią ogromne wyzwanie dla legislatorów. W konsekwencji sformułowania stosowane w tekście normatywnym stanowią zwykle swoisty kompromis pomiędzy precyzyjnością i ogólnością. Niedookreśloność to ważna cecha języka prawnego, a różne możliwości interpretacji jednego aktu prawnego nie kreują wieloznaczności same w sobie, ale raczej wywołują interpretacje dostosowane do aktualnych okoliczności. Wieloznaczność może być więc źródłem zarówno rozwoju prawa, jak i prawnej niejasności. Zwykle w legislacji obowiązuje więc bardzo ogólna zasada, że precyzja w wyrażeniach jest stosowana tam, gdzie jest to możliwe. Nieprecyzyjność można wyeliminować przez kontekst, czyli przez dodanie w sąsiedztwie wyrazu innych elementów lub umieszczenie wyrazu wśród innych elementów. Warto przy tym pamiętać o tym, że „niektóre rodzaje nieprecyzyjności moga stanowić większe zagrożenie dla porządku prawnego niż inne” (Solan 2005, 94).

\subsubsection{Interpretacja a modalność deontyczna}

Interpretacja tekstu prawnego w dużym stopniu uwarunkowana jest rozumieniem różnicy pomiędzy wypowiedzią normatywną a opisową. Maciej Zieliński (2002, 99-100) zwraca uwagę, że interpretując przepisy, normy w nich zawarte należy analizować na dwóch poziomach:

(i) deskryptywnym, gdzie tekst odczytywany jest jako wypadkowa znaczenia słów i reguł składni i jest on informacją o świecie, w którym np. za zabójstwo spotyka kogoś kara,

(ii) dyrektywnym, gdzie odczytuje się, jaki nakaz lub zakaz wyraża dany tekst. Jeżeli zdanie: „Kto zabija drugiego człowieka, podlega karze pozbawienia wolności” odczytane zostanie w sposób deskryptywny, będzie ono niosło zwyczajną informację o tym, w jaki sposób karze się za zabójstwo. Natomiast na poziomie dyrektywnym zdanie będzie odczytane w ten sposób, że zakazuje się zabijać i nadto nakazuje się za zabójstwo ukarać (por. Kaczmarek 2011, 64). 
Karolina KACZMAREK, Precyzja i niedookreśloność wyrażeń w przepisach...

Powyższy podział odpowiadać będzie zasadzie interpretacji literalnej i dyskursywnej. Właściwe odczytanie tekstu na poziomie dyrektywnym możliwe będzie po uwzględnieniu dyskursu, czyli faktu, że tekst należy odczytywać jako modalny deontycznie.

\section{Interpretacja semantyczna wyrazów w tekście normatywnym}

Jak zostało wcześniej wspomniane, zagadnienie precyzyjnego formułowania tekstu prawnego jest od wielu wieków dyskutowane przez filozofów prawa, a w chwili obecnej staje się również przedmiotem zainteresowania badaczy $\mathrm{z}$ innych obszarów nauk humanistycznych, w szczególności lingwistów. Niektórzy z nich (Christensen i Sokołowski 2002, 69-70, por. Bhatia et al. 2005, 15) wskazuja, że słowa same w sobie nie mają znaczenia, ponieważ każde słowo może zmienić swoje znaczenie w zależności od sposobu jego użycia, włączając $w$ to użycie $\mathrm{z}$ pozoru nieprawidłowe. Tak więc podział komponentów tekstu na „precyzyjne” i ,nieprecyzyjne” jest bezcelowe, ponieważ wszystkie elementy tekstowe są z natury nieprecyzyjne. Analogicznie, tak jak zwykły tekst nie niesie znaczenia sam $\mathrm{w}$ sobie, tak też teksty prawne nie będą miały znaczenia w oderwaniu od czynników, które im to znaczenie nadadza. Oznacza to, że na przykład sędzia nie może po prostu zajrzeć do słownika, by znaleźć właściwe rozwiązanie problemu. Zamiast tego, powinien on znaleźć rozsądne i przekonujące argumenty, które uzasadnią prawidłowość podjętej przez niego decyzji (Bhatia et al. 2005, 15).

$\mathrm{Za}$ przykład tego typu interpretacji w rozstrzygnięciu znaczenia wyrażenia nieostrego być świadomym może służyć sprawa obywatela amerykańskiego, który nielegalnie kupił broń w Ohio i odsprzedał ją w Nowym Jorku. Przepis stwierdzał, że do handlu bronia potrzebna jest licencja, a osoba oskarżona takiej licencji nie posiadała. W tym samym akcie prawnym zawarte było stwierdzenie, że temu, kto świadomie złamie powyższe prawo grozi kara pozbawienia wolności w wymiarze pięciu lat. Oskarżony bronił się, wskazujacc, że prawo mówi o tym, iż popełniający czyn musi być świadomy faktu, że popełnia przestępstwo. Nie ma natomiast dowodów na to, że oskarżony faktycznie był tego świadomy. Jednakże w tym wypadku, przy interpretacji przepisu sąd nie kierował się definicją słownikową poszczególnych wyrazów, tylko zaadaptował podejście do problemu na podstawie decyzji podejmowanych wcześniej w podobnych sprawach, stwierdzając, że wyraz świadomy często oznacza czyn popełniony celowo, lub $\mathrm{z}$ pełną świadomością, lub $\mathrm{z}$ własnej woli, odróżniając go od popełnionego przez przypadek. Ale kiedy wyraz ten stosuje się w prawie karnym, zasadniczo oznacza on czyn popełniony w świadomości złego celu, albo postępowanie charakteryzowało się niedbałością o to, czy dany czyn jest legalny czy nie. Sąd nie wybrał więc interpretacji najwęższej, tylko tę najbardziej odpowiednią do okoliczności (Solan 2005, 89).

\subsection{Niedookreśloność i nieostrość wyrażeń językowych}

Zarówno prawnicy, jak i lingwiści wskazują na liczne przykłady występowania wyrażeń nie do końca precyzyjnych w aktach prawnych konstruowanych w różnych językach i w różnych systemach prawnych. Jest to rodzaj konwencji stosowanej w sytuacji, gdzie 
konieczna jest generalizacja i elastyczność rozwiązań i gdzie precyzja i określoność nie jest ani konieczna ani wskazana.

W kontekście nieprecyzyjności języka w aktach normatywnych używa się w szczególności dwóch terminów:

(i) niedookreśloność,

(ii) nieostrość.

Termin „niedookreśloność” stosowany jest częściej w kontekście języka ogólnego, natomiast „nieostrość" występuje raczej w języku prawnym. Znaczenie tego ostatniego terminu może charakteryzować się wszelkimi wymienionymi wcześniej cechami niedookreśloności, będzie ono natomiast w szczególności dotyczyło świadomego działania legislatora, które ma na celu zwiększenie stopnia ogólności wypowiedzi. Zastosowanie wyrazu nieostrego w takim znaczeniu nie będzie prowadziło do niejednoznaczności wypowiedzi i nie ma konieczności jego precyzowania, ponieważ w określonej sytuacji uczestnicy aktu komunikacji mają wystarczająco dużo informacji, żeby wybrać właściwe znaczenie słowa (por. Pinkal 1981, 10, Bhatia et al. 2005, 12). Niedookreśloność, czy też nieostrość semantyczna, stanowi więc cechę charakterystyczną języka prawa, co więcej, można stwierdzić, że wystapienie tej cechy jest konieczne, by akty normatywne były produktywne, to znaczy by miały zastosowanie w wielu przypadkach, w różnych okolicznościach.

Niedookreśloność wypowiedzi może być różnego typu, z czego najczęściej wymienia się:

(i) niejednoznaczność (ambiwalencję) - w tym wypadku wyraz oznacza, że jedno słowo posiada dwa lub więcej znaczeń,

(ii) niejasność - oznacza, że granica między desygnatami słów może być trudna do określenia.

Wyrażenia semantycznie niedookreślone są „niejasne”, jeżeli ich zastosowanie prowadzi do niejasności komunikacyjnej w sytuacji, gdzie kontekst czy innego rodzaju dopowiedzenie nie stanowi czynnika rozstrzygającego wątpliwości. Konieczne jest więc dalsze uściślenie wypowiedzi, ponieważ odbiorca wie, że wypowiedź odnosi się do ograniczonej liczby alternatywnych znaczeń, jednakże nie wie, które ze znaczeń powinno być przypisane w danym wypadku (por. Pinkal 1981, 10, Bhatia et al. 2005, 12). Zasadniczo wyrażenie niedookreślone powinno być stosowane świadomie, a zwiększenie stopnia precyzji wypowiedzi - jeżeli zaistnieje taka potrzeba - powinno być możliwe przynajmniej w pewnym stopniu.

Niektóre wyrazy, mimo że wydają się semantycznie niedookreślone, to $\mathrm{w}$ dyskursie prawnym są bardzo precyzyjne, a z kolei inne pozostają niedoprecyzowane. Endicott $(2005,30)$ wskazuje na przykład, że w wyrażeniu child or young person brytyjski ustawodawca dokładnie określa, że chodzi o osobę poniżej szesnastego roku życia. Podobnie w ustawodawstwie polskim Kodeks karny rozróżnia:

(i) nieletniego - jest to osoba przed ukończeniem 17 lat, i

(ii) mtodocianego - jest to osoba, która popełnia czyn zabroniony przed ukończeniem 21 lat, ale ukończyła 24 lata, zanim zapadło orzeczenie w pierwszej instancji. 
Karolina KACZMAREK, Precyzja i niedookreśloność wyrażeń w przepisach...

Z kolei polski Kodeks cywilny wyróżnia małoletniego - jest to osoba przed ukończeniem 18 roku życia, natomiast Kodeks pracy, tak jak Kodeks karny, wymienia młodocianego z tym, że w przypadku prawa pracy, jest to osoba pomiędzy 16 a 18 rokiem życia. Według węgierskiego Kodeksu cywilnego kiskorú to „18 éven aluli gyermek” (dziecko poniżej 18 roku życia), chyba że osoba ta zawarła już związek małżeński. W Kodeksie karnym natomiast występuje fiatalkorú, czyli taka osoba, która w momencie popełnienia przestępstwa ukończyła 14 rok życia, ale nie ukończyła 18 roku życia.

Podobnej pewności co do znaczenia wyrazów nie ma już natomiast przy stwierdzeniu, że dziecko nie może być pozostawione bez opieki, ponieważ ustawa nie stwierdza jednoznacznie, ile lat ma mieć opiekun. Na przykład brytyjska ustawa mówi tylko, dość nieprecyzyjnie, że opieka powinna być zapewniona w taki sposób, by dziecko nie było „zaniedbane”, „opuszczone” i pozostawione „w takich warunkach, gdzie byłoby narażone na niepotrzebne cierpienie lub uszkodzenia fizyczne". Tak więc, dla zwiększenia precyzyjności wyrażenia zapewnić opieke zastosowano inne zwroty nieprecyzyjne. Jak wiadomo, zagadnienia związane $\mathrm{z}$ zapewnieniem właściwej opieki dzieciom sa diametralnie różnie rozumiane $\mathrm{w}$ różnych środowiskach, krajach i regionach świata. Podczas gdy w niektórych krajach kryterium właściwej opieki nad dzieckiem będzie zapewnienie mu podstawowej porcji żywności, co więcej, brak takiej żywności nie wpłynie w żaden sposób na ewentualną ingerencję władz w życie rodziny, w innym kraju ingerencja może nastapić, gdy warunki życia nawet tylko w nieznacznym stopniu odbiegają od powszechnych standardów życia społecznego, na przykład w kwestii statusu materialnego rodziców. Dlatego, jak wskazuje Endicott $(2005,41)$ :

„Prawo nie może być stosowane przeciwko rodzicom, których metody wychowawcze są po prostu ekscentryczne, co więcej, nawet bycie złym rodzicem nie jest samo w sobie usprawiedliwieniem dla ingerencji prawnej w życie rodziny: prawo powinno być wdrażane tylko w przypadku czynników powodujących szczególnie dużą krzywdę dziecka".

Dyskusja o nieprecyzyjności trwa po dziś dzień w wielu instytucjach i w ramach różnych systemów prawnych. Na przykład sąd apelacyjny w Kanadzie (por. Giannoni 2005, 439) w 2002 roku uznał nieokreśloność za zjawisko niepożądane, które może powodować nieważność procesów sądowych oraz być przyczyną sędziowskiej samowoli. Jak stwierdził sąd:

„Nieokreśloność nie może być analizowana w oderwaniu od innych czynników, tylko powinna być oceniana $\mathrm{w}$ ramach szerokiego kontekstu rozwiniętego przez analizę różnych czynników, takich jak cel, istota sprawy, natura dotyczących sprawy przepisów, wartości społeczne, podobne przepisy prawa”.

Takie podejście stanowi odzwierciedlenie kompleksowej natury zjawiska, które, czy to w sposób intencjonalny, czy też nie, jest cechą charakterystyczną dyskursu prawnego, zarówno w jego odmianie pisanej, jak i mówionej. Omawiana powyżej kwestia nieokreśloności staje się jeszcze bardziej zawiła, gdy mówi się o przepisach prawa o zasięgu globalnym. 


\subsection{Nieprecyzyjność i ambiwalencja}

Lingwiści zwracają uwagę na różnicę między zjawiskiem nieprecyzyjności semantycznej i ambiwalencji. Lawrence M. Solan $(2005,73)$ uważa, że nieprecyzyjność powstaje w sytuacjach „granicznych”, to znaczy tam, gdzie trudno jest określić, czy pewna koncepcja należy do danej kategorii, czy też nie. Przy czym nieprecyzyjność to zjawisko występujące często. Jedną $\mathrm{z}$ przyczyn jest fakt, iż odbiorcy różnie rozumieją poszczególne słowa, na przykład przyporządkowują je do odmiennych kategorii. Natomiast ambiwalencja dotyczy sytuacji, gdzie jakieś wyrażenie ma dwa lub więcej precyzyjnie określonych znaczeń, czyli odbiorca tekstu dokonuje wyboru pomiędzy pewną liczbą alternatywnych znaczeń i wiąże się zwykle $\mathrm{z}$ występowaniem homonimii, polisemii, metafory, elipsy, syntaksy i niedookreślonych referentów. W tekstach specjalistycznych ambiwalencja zdarza się stosunkowo rzadko i w większości przypadków wątpliwości rozstrzyga kontekst wypowiedzi (por. Giannoni 2005, 438).

\section{Narzędzia zwiększania precyzji tekstowej}

Jak już zostało wspomniane, prawo $\mathrm{z}$ jednej strony jest wyrażane w sposób bardzo ogólny, z drugiej strony natomiast daż̇y do dużej precyzji. Precyzję tekstową można zwiększyć w różny sposób. Do czynników wpływających na zwiększenie precyzji tekstowej możemy zaliczyć między innymi:

(i) sporządzenie definicji terminów,

(ii) umieszczanie wyrazów w odpowiednim kontekście tekstowym,

(iii) wyznaczenie granicy nieostrości,

(iv) doprecyzowanie interpretacyjne,

(v) określenie warunków stosowania prawa,

(vi) doprecyzowanie semantyczne.

\subsection{Sporządzenie definicji terminów}

Jedną z metod precyzowania tekstów prawnych jest definiowanie terminów. Ma ono na celu wyraźne określenie znaczenia wyrazu w danym tekście normatywnym, szczególnie w kontraście do jego powszechnego rozumienia w języku ogólnym. W definicjach i określeniach pojęć często stosuje się zdania wielokrotnie złożone, gdzie zdanie główne przyporządkowuje pojęcie do jakiejś większej grupy (klasy, kategorii), a zdania poboczne wymieniają ich najważniejsze cechy (por. Kaczmarek 2011, 92).

Istnieje kilka rodzajów definicji, zróżnicowanych ze względu na strukturę i sposób precyzowania treści. Definicje mogą być zawarte w słowniczku na początku aktu normatywnego lub w nawiasach w ramach akapitów czy też klauzul umownych. Definicje składają się zazwyczaj z definiensa, definiendum i łącznika. Treść może być sprecyzowana przez określenie zakresu kotekstu, to znaczy określenie w ramach jakiego tekstu dana definicja funkcjonuje jako obowiązująca i z jakimi innymi tekstami jest powiązana. 
Karolina KACZMAREK, Precyzja i niedookreśloność wyrażeń w przepisach...

W tabeli zawarte są przykłady zwrotów z definicji, które wskazują na różnego rodzaju odniesienia tekstowe:

Tabela 1. Przykłady zwrotów z definicji, które wskazują na różnego rodzaju odniesienia tekstowe.

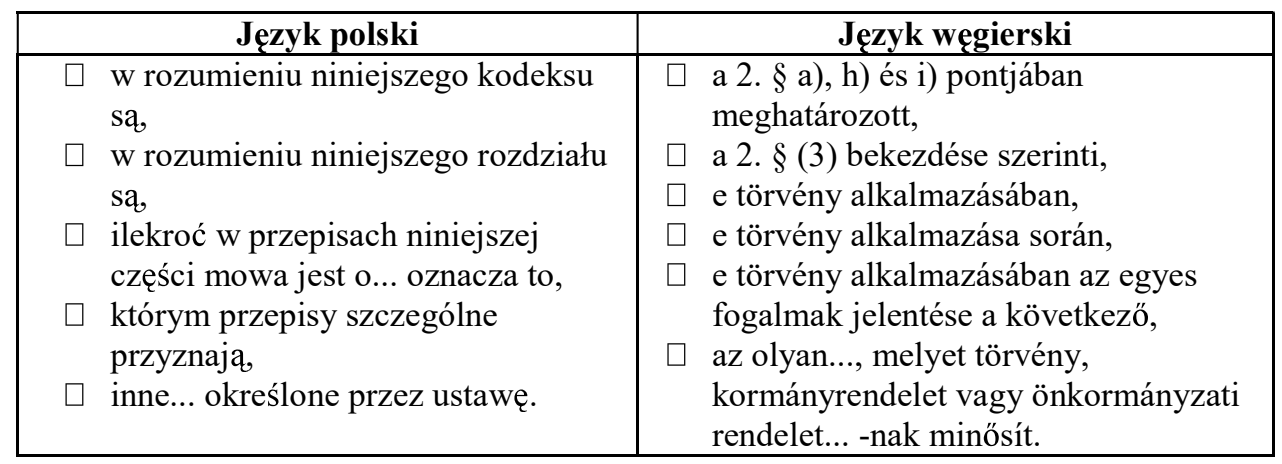

Rolę łącznika w definicji legalnej pełnić mogą między innymi następujące zwroty:

Tabela 2. Zwroty pełniace funkcję łącznika w definicji legalnej.

\begin{tabular}{|l|l|}
\hline \multicolumn{1}{|c|}{ Język polski } & \multicolumn{1}{c|}{ Język węgierski } \\
\hline$\square$ jest to, & $\square$ kell tekinteni, \\
$\square$ są to, & $\square$ minösül, \\
$\square$ jest, kto, & $\square$ nem minősül, \\
$\square$ jest, & $\square$ érteni kell. \\
$\square$ sa, & \\
$\square$ to, & \\
$\square$ oznacza, & \\
$\square$ oznaczaja, & \\
$\square$ przez... rozumie się, & \\
$\square$ rozumie się przez to, & \\
$\square$ za... uważa się, & \\
$\square$ określa, & \\
$\square$ jest nazywane, & \\
$\square$ odnosi się do. & \\
\hline
\end{tabular}

Warto zaznaczyć, że najczęściej stosowany w języku polskim zwrot ... jest ... (lub ... sq ...), jest przez polskich teoretyków prawa (Zieliński 2002) uważany za nieprawidłowy. Wyrażenie, które jest używane rzadziej, ale byłoby bardziej prawidłowe, to ... jest to ..., ... sq to ... (por. Kaczmarek i Matulewska 2006).

Niektóre definicje terminów mogą być sformułowane w taki sposób, że termin w dalszym ciagu pozostanie niedookreślony. Tego typu zjawisko wystapi szczególnie 
w zdaniach zawierających spójnik „lub”, który może oznaczać albo alternatywę, albo włączenie, czy też spójnik ,i”, który najczęściej występuje w znaczeniu dodania czegoś, ale czasami też jako alternatywa.

\subsection{Umieszczanie wyrazów w odpowiednim kontekście tekstowym}

Jednym ze sposobów doprecyzowywania wyrażeń ogólnych w tekście prawnym jest umieszczanie ich w odpowiednim kontekście tekstowym (nazywanym też kotekstem). Specyficzne sąsiedztwo wyrazowe powoduje, że treści implicytne stają się eksplicytne. Doprecyzowanie może odnosić się do:

(i) komponentu wewnętrznego,

(ii) komponentu zewnętrznego,

(iii) nazwy kontekstowej.

Wyrażenie komponent wewnętrzny dotyczy takich zwrotów, które występuja w treści zdania lub tekstu, na przykład w relacji hiponimii i hiperonimii. Doprecyzowanie może być uzyskane między innymi za pomocą takich zwrotów jak:

(i) $\quad$ szczególności, np. ryby, a w szczególności karpie,

(ii) $\quad$ właczajac $w$ to, np. pojazdy, włączając $\mathrm{w}$ to pojazdy rolnicze.

Komponent zewnętrzny dotyczy takich treści wewnątrztekstowych, które są w dużym stopniu determinowane przez czynniki i źródła pozatekstowe. Co więcej, źródła te odgrywaja decydującą rolę przy konstruowaniu i interpretacji przepisów prawnych. Po wyrażeniach typu $z$ uwzględnieniem, biorac pod uwage, w zależności od, kierujac się, zostaje przytoczony pewien fakt, opisany dyskurs, rzeczywistość, która znajduje się najczęściej poza zdaniem czy też tekstem.

Przykład nr 1 - zastosowanie wyrażenia w języku polskim:

KC Art. 359 § 3. Rada Ministrów określa, w drodze rozporządzenia, wysokość odsetek ustawowych, kierując się koniecznością zapewnienia dyscypliny płatniczej i sprawnego przeprowadzania rozliczeń pieniężnych, biorąc pod uwage wysokość rynkowych stóp procentowych oraz stóp procentowych Narodowego Banku Polskiego.

Przykład nr 2 - zastosowanie wyrażenia w języku węgierskim:

Ptk. 358 § (1) A baleset következtében meghalt személy által eltartottak olyan összegü tartást pótló járadékot igényelhetnek, amely szükségleteiknek - a tényleges, illetőleg az elvárhatóan elérhető keresetüket (jövedelmüket) is figyelembe véve - a baleset elötti életszínvonalon való kielégítését biztosítja.

Wyrażenie nazwa kontekstowa dotyczy sytuacji, gdzie pewne terminy są zasadniczo jasne, ze względu na wiedzę kontekstową odbiorców. Na przykład w określeniu dlugi staż pracy świadomy użytkownik języka będzie wiedział, że chodzi o czas liczony w latach, przy czym nazwa kontekstowa może zostać jeszcze dokładniej 
doprecyzowana. W przypadku frazy dlugi staż pracy $w$ górnictwie otrzymujemy informację, że staż pracy jest krótszy niż w innych zawodach (Wronkowska i Zieliński 1997, 167, Kaczmarek 2011, 91).

\subsection{Wyznaczenie granicy nieostrości}

Granicę nieostrości terminu możemy wyznaczyć na przykład poprzez określenie czasu trwania od dwóch do sześciu lat. W zasadach techniki prawodawczej zawarte jest zalecenie, by postanowienia obniżające górną granicę swobody rozstrzygnięcia wyrażać konsekwentnie przez posługiwanie się formułami: nie przekraczajace albo nie więcej niż, a postanowienia podwyższające dolną granicę swobody rozstrzygnięcia powinny mieć postać nie niżej niż albo nie mniej niż (Wronkowska i Zieliński 1997, 167, Kaczmarek 2011, 91).

\subsection{Doprecyzowanie interpretacyjne}

Zdanie ,jeżeli przepisy niniejszej ustawy dotyczą ... to odnoszą się również do ..." eksplicytnie wyraża, jaki rodzaj wykładni prawnej powinien zostać zastosowany dla danego przepisu. W tym wypadku chodzi o dokonanie wykładni porównawczej oraz/lub zastosowanie tzw. reguł interferencyjnych oznaczających, że jeżeli coś jest nieustalone, to kwestię rozwiązuje się w drodze analogii z innym przepisem, dotyczącym podobnych spraw (por. Kaczmarek 2011, 62).

\subsection{Określenie warunków ograniczających stosowanie prawa}

Niekiedy ograniczenie zakresu następuje przez określenie warunków, w jakich dany przepis może zostać zrealizowany. Językowo wyraża się to najczęściej poprzez konstrukcję zdania warunkowego. Należy zaznaczyć, że tego typu zdanie występuje w aktach normatywnych szczególnie często. Oprócz konstrukcji zdania warunkowego, istnieje wiele wyrażeń, które mogą wskazywać na istnienie ograniczeń dla realizacji zapisów danego przepisu.

Tabela 3. Przykładowe struktury zdania warunkowego.

\begin{tabular}{|c|c|}
\hline Język polski & \multicolumn{1}{c|}{ Język weggierski } \\
\hline$\square$ jeżeli ... to ... & $\square$ ha .., (akkor), \\
& $\square$ ha .., de ..., \\
& $\square$ ha ..., és ezért ..., \\
& $\square$ ha ... nem ... (akkor), \\
& $\square$ ha (a körülményekböl), kifejezetten \\
& más nem következik, \\
& $\square$ ha (a törvény) másként nem \\
& rendelkezik. \\
\hline
\end{tabular}

Również innego rodzaju zwroty mogą warunkować realizację przepisów, na przykład: 
Tabela 4. Inne zwroty mogące warunkować realizację przepisów.

\begin{tabular}{|l|ll|}
\hline \multicolumn{1}{|c|}{ Język polski } & \multicolumn{1}{c|}{ Język węgierski } \\
\hline$\square$ chyba że, & $\square$ & (körülményeken) kívül, \\
$\square$ aż do, & $\square$ csak akkor, ha, \\
$\square$ wyłącznie, & $\square$ feltéve, hogy..., \\
$\square$ z wyłączeniem, & $\square$ kivéve, \\
$\square$ o ile (ustawa) nie stanowi inaczej. & $\square \quad$ anélkül, hogy..., \\
& $\square \quad$ minden... akinek nem... \\
\hline
\end{tabular}

Przykład nr 3 - zastosowanie wyrażenia w przepisie polskim:

KC Art. 3. Ustawa nie ma mocy wstecznej, chyba że to wynika z jej brzmienia lub celu.

Przykład nr 4 - zastosowanie wyrażenia w przepisie węgierskim:

Ptk. 75 § (3) A személyhez füződő jogokat nem sérti az a magatartás, amelyhez a jogosult hozzájárult, feltéve, hogy a hozzájárulás megadása társadalmi érdeket nem sért vagy veszélyeztet.

\subsection{Doprecyzowanie semantyczne}

Doprecyzowanie semantyczne może być klasyfikowane ze względu na różne cechy. Może ono dotyczyć między innymi takich kwestii jak:

(i) dostosowanie sposobu realizacji prawa do okoliczności i lokalnych warunków społeczno-kulturowych, na przykład:

Tabela 5. Przykładydostosowania sposobu realizacji prawa do okoliczności i lokalnych warunków społeczno-kulturowych.

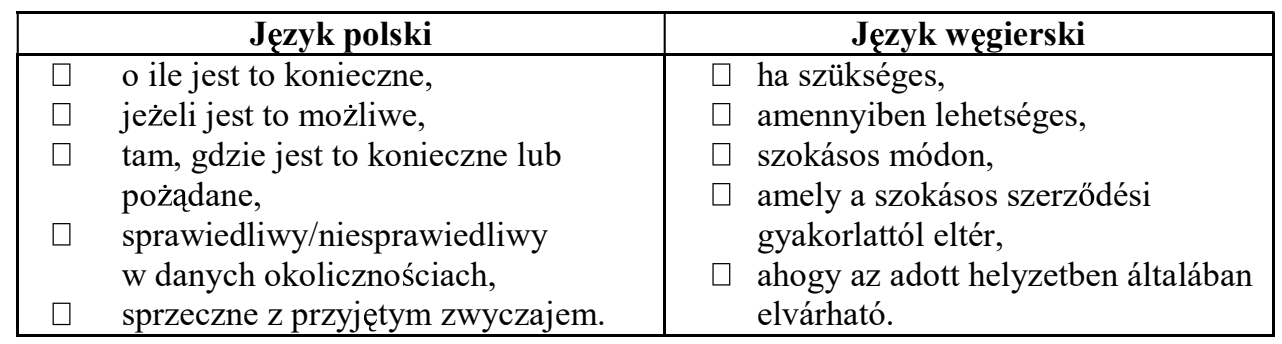

Przykład nr 5 - zastosowanie wyrażenia w przepisie polskim:

KC Art. 56. Czynność prawna wywołuje nie tylko skutki w niej wyrażone, lecz również te, które wynikają $\mathrm{z}$ ustawy, $\mathrm{z}$ zasad wspólżycia spolecznego i z ustalonych zwyczajów. 
Karolina KACZMAREK, Precyzja i niedookreśloność wyrażeń w przepisach...

Przykład nr 6 - zastosowania wyrażenia w przepisie węgierskim:

Ptk. $10 \S$ A gyermek részére már megszületése előtt gondnokot kell kirendelni, $h a$ ez jogainak megóvása érdekében szükséges.

(ii) uwzględnienie przy realizacji prawa treści zawartych $\mathrm{w}$ innym tekście lub zgodnie z innego rodzaju normami, na przykład:

Tabela 6. Przykłady uwzględnienia treści zawartych w innym tekście lub zgodnie $\mathrm{z}$ innego rodzaju normami.

\begin{tabular}{|l|l|}
\hline \multicolumn{1}{|c|}{ Język polski } & \multicolumn{1}{c|}{ Język węgierski } \\
\hline$\square$ według, & $\square$ szerint, \\
$\square \quad$ zgodnie z, & $\square$ egyezö, \\
$\square \quad$ biorąc pod uwagę. & $\square$ tekintettel. \\
\hline
\end{tabular}

Przykład nr 7 - zastosowanie wyrażenia w przepisie polskim:

KC Art. $70^{1} \S 4$. Organizator od chwili udostępnienia warunków, a oferent od chwili złożenia oferty zgodnie $\mathrm{z}$ ogłoszeniem aukcji albo przetargu sa obowiązani postępować zgodnie $z$ postanowieniami ogłoszenia, a także warunków aukcji albo przetargu.

Przykład nr 8 - zastosowanie wyrażenia w przepisie węgierskim:

Ptk. 469 § [...] Ennek elmulasztása esetén a szálloda a kárért az általános szabályok szerint tartozik felelősséggel.

(iii) określenie terminu i sposobu realizacji zapisów prawa, na przykład:

Tabela 7. Przykłady określaniaterminu i sposobu realizacji zapisów prawa.

\begin{tabular}{|l|l|}
\hline \multicolumn{1}{|c|}{ Język polski } & \multicolumn{1}{c|}{ Język węgierski } \\
\hline$\square$ jak najszybciej, & $\square$ a körülmények által lehetővé tett \\
& legrövidebb időn belül, \\
$\square$ stopniowo, & $\square$ rövid idő alatt, \\
$\square$ natychmiast, bezzwłocznie, & $\square$ által. \\
$\square$ za pomoca (czegoś), & \\
$\square \quad$ przez (kogoś). & \\
\hline
\end{tabular}

Przykład nr 9 - zastosowanie wyrażenia w przepisie polskim:

Art. $66^{1} \S 4$. Przepisy $\S 1-3$ nie mają zastosowania do zawierania umów za pomoca poczty elektronicznej. 
Przykład nr 10 - zastosowanie wyrażenia w przepisie węgierskim:

A Ptk. $232 \S(3)$ A felek által túlzott mértékben megállapított kamatot a bíróság mérsékelheti.

(iv) określenie zakresu znaczeniowego słowa poprzez porównanie, na przykład:

Tabela 8. Przykłady określania zakresu znaczeniowego słowa poprzez porównanie.

\begin{tabular}{|l|l|}
\hline \multicolumn{1}{|c|}{ Język polski } & \multicolumn{1}{c|}{ Język węgierski } \\
\hline$\square$ tak jak, & $\square$ úgy, ahogy, \\
$\square$ tak jakby. & $\square$ úgy, mintha. \\
\hline
\end{tabular}

Przykład nr 11 - zastosowanie wyrażenia w przepisie polskim:

KC Art. 1020. Spadkobierca, który spadek odrzucił, zostaje wyłączony od dziedziczenia, tak jakby nie dożył otwarcia spadku.

Przykład nr 12 - zastosowanie wyrażenia w przepisie węgierskim:

Ptk. $463 \S(2)$ A letéteményes a jogosan igénybe vett harmadik személy magatartásáért úgy felel, mintha a dolgot ő maga őrizte volna.

\section{Klasyfikacja gramatyczna wyrażeń niedookreślonych}

Wyrażenia niedookreślone można pogrupować między innymi ze względu na ich funkcje gramatyczne. Poniżej zamieszczone zostały przykłady wyrazów, które z jednej strony sa szczególnie ogólnikowe, i dzięki temu mogą być szeroko stosowane w aktach prawnych wyższego rzędu, takich jak na przykład ustawa, a z drugiej strony niejednokrotnie moga służyć jako narzędzia doprecyzowywania wyrazów należących do innych kategorii gramatycznych. Ze względu na rozległość tej klasyfikacji poniżej podane zostaną tylko wybrane części mowy.

\subsection{Przymiotniki}

Przymiotniki, które ze względu na cechę ogólnikowości możemy nazwać nieostrymi, bardzo często służą jako narzędzie doprecyzowywania rzeczowników. Do grupy tej w języku polskim zaliczymy takie przymiotniki jak na przykład:

adekwatny, akceptowalny, błahy, celowy, częsty, dobry, dogodny, dostateczny, duży, godziwy, istotny, kluczowy, kompetentny, konieczny, korzystny, mały, możliwy, nadmierny, naturalny, niedbały, niemożliwy, nieodpowiedni, niepokojący, niepożądany, nieprawdopodobny, nierozsąny, nierozważny, niesłuszny, niestaranny, nieuzasadniony, niewielki, niewłaściwy, niewygórowany, niezbędny, nieznaczny, normalny, obiektywny, oczywisty, odpowiedni, odpowiedzialny, poważny, pożądany, prawdopodobny, 
Karolina KACZMAREK, Precyzja i niedookreśloność wyrażeń w przepisach...

przewidywalny, rozsądny, rozważny, rzadki, satysfakcjonujący, słuszny, sprawiedliwy, stosowny, umiarkowany, uzasadniony, ważny, właściwy, wskazany, wygórowany, wyjątkowy, wyraźny, wystarczający, zadowalający, zły, znaczący, znaczny, zwykły. przymiotniki:

W języku węgierskim do tego typu grupy zaliczymy na przykład następujące aránytalan, csekély, elegendő, elháríthatatlan, elvárható, indokolatlan, jelentéktelen, jelentős, kellő, kisebb, különösebb, megfelelő, méltányos, menthető, szokásos.

Niedookreślone przymiotniki mogą być dookreślane przez inne wyrazy, na przykład:

Tabela 9. Przymiotniki niedookreślone dookreślane przez inne wyrazy.

\begin{tabular}{|l|l|}
\hline \multicolumn{1}{|c|}{ Język polski } & \multicolumn{1}{c|}{ Język węgierski } \\
\hline$\square$ bardzo piękny, & $\square$ kevésbé biztosított (követelés), \\
$\square$ mało prawdopodobny, & $\square$ a legalacsonyabb eladási (ár), \\
$\square$ dość prawdopodobny, & $\begin{array}{l}\square \text { a biztosítani kívánt legmagasabb } \\
\text { (összeg), }\end{array}$ \\
$\square$ szeroko rozpowszechniony (zwyczaj), \\
$\square$ szczególnie niski (dochód). & $\begin{array}{l}\text { a körülmények által lehetővé tett } \\
\text { legrövidebb (idö). }\end{array}$ \\
\hline
\end{tabular}

Przykład nr 13 - zastosowanie przymiotnika niedookreślonego w przepisie polskim:

KC Art. $7602 \S 2$. Dający zlecenie obowiązany jest $w$ rozsqdnym czasie zawiadomić agenta o przyjęciu lub odrzuceniu propozycji zawarcia umowy oraz o niewykonaniu umowy, przy której zawarciu agent pośredniczył lub którą zawarł w imieniu dającego zlecenie.

Przykład nr 14 - zastosowanie przymiotnika niedookreślonego w przepisie węgierskim:

Ptk. 370 § (3) Ha a tehermentesítés lehetetlen, vagy aránytalan költséggel járna, a vevő a szerződéstől elállhat, és kártérítést követelhet, vagy a teher átvállalása fejében a vételár megfelelő csökkentését követelheti.

Należy zauważyć, że w języku węgierskim istnieją szczególnie szerokie możliwości rozbudowywania ciagów przydawek dookreślających wyrazy, tak więc również w języku prawnym jest to bardzo charakterystyczny sposób doprecyzowywania wyrażeń. 


\subsection{Przyslówki}

Do grupy przysłówków nieostrych w języku polskim zaliczymy na przykład następujące wyrazy:

częściowo, dosyć, dość, głównie, możliwie, nieco, niemal, nieznacznie, odpowiednio, około, ostrożnie, potencjalnie, pozornie, prawie, zasadniczo.

Do grupy przysłówków nieostrych w języku węgierskim zaliczymy między innymi następujące wyrazy:

megfelelően, nagymértékben, részlegesen, tőmegesen.

Przykład nr 15 - zastosowanie przysłówka niedookreślonego w przepisie polskim:

KC Art. $948 \S 1$. Testament należy tak thumaczyć, ażeby zapewnić możliwie najpełniejsze urzeczywistnienie woli spadkodawcy.

Przykład nr 16 - zastosowanie przysłówka niedookreślonego w przepisie węgierskim:

Ptk. 491 § (2) A fuvarozó köteles az átadott okmányokat megfelelöen felhasználni.

\subsection{Rzeczowniki}

Do grupy rzeczowników nieostrych w języku polskim zaliczymy między innymi następujące wyrazy:

bezstronność, mniejszość, przejrzystość, skuteczność, sprawiedliwość, większość.

Do grupy rzeczowników nieostrych w języku węgierskim zaliczymy między innymi następujące wyrazy:

átláthatóság, eredményesség, jóhiszeműség, méltányosság, pártatlanság, rosszhiszemüség.

Warto zaznaczyć, że w języku węgierskim, ze względu na znaczną produktywność w kwestii tworzenia wyrazów złożonych, wystapi więcej wyrazów, które zaliczymy do kategorii rzeczowników nieostrych, niż w języku polskim. Na przykład terminy rosszhiszemüség i jóhiszemüség w języku węgierskim funkcjonuja jako rzeczowniki złożone, a w języku polskim jako połączenie rzeczownika z przymiotnikiem w zwrotach dobra wiara i zła wiara.

Przykłady zastosowania rzeczowników nieostrych w legislacji Unii Europejskiej (KOM: 2011): 
Karolina KACZMAREK, Precyzja i niedookreśloność wyrażeń w przepisach...

Przykład nr 17 - język polski:

Ich zdaniem skuteczne procedury ADR powinny kierować się wspólnymi zasadami, takimi jak bezstronnossć, przejrzystość, skuteczność i sprawiedliwossć.

Przykład nr 18 - język węgierski:

A vélemények szerint a hatékony alternatív vitarendezési folyamatokat olyan közös elvek alapján kell kialakítani, mint a pártatlanság, átláthatóság, eredményesség és méltányosság.

\section{Uwagi końcowe}

W dokumencie Parlamentu Europejskiego, Rady i Komisji Wspólny przewodnik praktyczny dotyczacy redagowania aktów prawa wspólnotowego (http://eur-lex.europa. eu/pl/techleg/index. htm) znajduje się zapis mówiący o tym, że akty przyjmowane przez instytucje Wspólnoty muszą być sporządzone w sposób zrozumiały i konsekwentny, aby obywatele i podmioty gospodarcze mogli rozpoznać swoje prawa i obowiązki i aby sądy mogły je egzekwować. Wskazuje się, iż idea ta jest wyrazem ogólnych zasad prawa. Jedna z nich jest równość obywateli wobec państwa, w takim sensie, że prawo powinno być dostępne i zrozumiałe dla wszystkich. Druga zasada to pewność prawa, to znaczy że istnieje możliwość przewidzenia, w jaki sposób prawo będzie stosowane. Wydaje się, że prawo unijne, ze względu na swoją specyfikę wielonarodowościową i wielojęzyczność, wymaga większego stopnia precyzji niż prawa krajowe, gdzie w dużym stopniu o znaczeniu i interpretacji decyduje znany obywatelom dyskurs lokalny. Nie ma natomiast wattpliwości co do tego, że zagadnienie precyzyjności formułowania tekstu prawnego jest bardzo szerokie i jego analiza z możliwie wielu punktów widzenia oraz stosowanie przy formułowaniu tekstów uporządkowanych kryteriów lingwistycznych może przyczynić się do uzyskania przez odbiorcę możliwie wysokiego stopnia pewności co do tego, co w prawie, które bezpośrednio go dotyczy, jest zakazane, nakazane czy też dozwolone. 


\section{Bibliografia}

Vijay K. Bhatia, Jan Engberg, Maurizio Gotti i Dorothee Heller, red. 2005. Vagueness in Normative Texts. Linguistic Insights. Studies in Language and Communication. Vol. 23. Bern: Peter Lang.

Christensen, Ralph i Michael Sokolowski, 2002. Wie normative ist Sprache? Der Richter zwischen Sprechautomat und Sprachgesetzgeber. W Ulrike Haß-Zumkehr, red. Sprache und Recht, ss. 64-79. Berlin/New York: de Gruyter.

Endicott, Timothy, 2005. The Value of Vagueness. [W:] Vijay K. Bhatia, Jan Engberg, Maurizio Gotti i Dorothee Heller, red. Vagueness in Normative Texts. Linguistic Insights. Studies in Language and Communication nr 23, 27-48. Bern: Peter Lang.

Giannoni, Davide, Simone, 2005. 'Any dispute shall be settled by arbitration': A Study of Vagueness in International Model Arbitration Clauses. [W:] Vijay K. Bhatia, Jan Engberg, Maurizio Gotti i Dorothee Heller, red. 2005. Vagueness in Normative Texts. Linguistic Insights. Studies in Language and Communication $\mathrm{nr} 23,437-468$. Bern: Peter Lang.

Grzybek, Joanna, 2009. Polysemy, homonymy and other sources of ambiguity in the language of Chinese contracts. W Comparative Legilinguistics: International Journal for Legal Communication $\mathrm{nr} 1 / 2009,207-215$.

Kaczmarek, Karolina, 2011. Lingua legis $\mathrm{w}$ aspekcie translatologicznym węgiersko-polskim i polsko-węgierskim. [W:] Legilingwistyka porównawcza $\mathrm{nr}$ 6/2011, 9-228.

Kaczmarek, Karolina i Aleksandra Matulewska, 2006. Legal Definitions in English, Hungarian and Polish Statutory Documents. [W:] Investigationes Linguisticae nr XIII, 86-101.

Matulewska, Aleksandra, 2007. Lingua Legis in Translation. Peter Lang Publishing House.

Pinkal, Manfred, 1981. Semantische Vagheit: Phänomene und Theorien, Teil I. Linguistische Berichte 70, 1-26.

Solan, Lawrence, 2005. Vagueness and Ambiguity in Legal Interpretation. [W:] Vijay K. Bhatia, Jan Engberg, Maurizio Gotti i Dorothee Heller, red. Vagueness in Normative Texts. Linguistic Insights. Studies in Language and Communication $\mathrm{nr} 23,73-96$. Bern: Peter Lang.

Stawecki, Tomasz, i Piotr Winczorek, 2002. Wstep do prawoznawstwa. Warszawa: Wyd. C. H. Beck.

Tiersma, Peter, M., 2005. Categorical Lists in the Law. [W:] Vijay K. Bhatia, Jan Engberg, Maurizio Gotti i Dorothee Heller, red. Vagueness in Normative Texts. Linguistic Insights. Studies in Language and Communication nr 23, 109-132. Bern: Peter Lang.

Wronkowska, Stanisława i Maciej Zieliński, 1997. Zasady techniki prawodawczej. Komentarz. Warszawa: Wydawnictwo Sejmowe.

Zieliński, Maciej, 2002. Wykładnia prawa. Zasady. Reguly. Wskazówki. Warszawa: Wydawnictwo Prawnicze LexisNexis.

\section{Wykaz dokumentów prawnych}

1959. évi IV. törvény a Polgári Törvénykönyvröl.

KOM (2011) 793, Wniosek, Dyrektywa Parlamentu Europejskiego I Rady w sprawie alternatywnych metod rozstrzygania sporów konsumenckich.

Rozporządzenie Prezesa Rady Ministrów z dnia 2 czerwca 2002 roku w sprawie "Zasad techniki prawodawczej" (Dz. U. Nr 100 poz. 908 z dnia 5 lipca 2002 r.).

Ustawa z dnia 23 kwietnia 1964 r. Kodeks Cywilny.

Wspólny przewodnik praktyczny dotyczący redagowania aktów prawa wspólnotowego. http://eurlex. europa. eu/pl/techleg/index. htm. 